\title{
THE ASSESSMENT OF LACTATE IN EXPERIMENTAL ACUTE MYOCARDIAL INFARCTION
}

\author{
Victor TIMERCAN ${ }^{1}$, Tatiana TIMERCAN ${ }^{1 \otimes}$ \\ ${ }^{1}$ Department of Biochemistry and Clinical Biochemistry, "Nicolae Testemitanu" State University of \\ Medicine and Pharmacy, Chisinau, Republic of Moldova \\ Received 01 Oct 2021, Accepted 05 Nov 2021 \\ hitps://doi.org/10.31688/ABMU.2021.56.4.07
}

\begin{abstract}
Introduction. Metabolism is the key factor underlying the cardiomyocyte function. The inadequate coronary perfusion results in tissue acidosis due to elevated lactate production, which is considered a sensitive marker of myocardial ischemia. Isoproterenol is a synthetic catecholamine that produces diffuse myocardial necrosis at high doses.
\end{abstract}

The aim of the study was to assess the changes of serum and tissue lactate content in isoproterenol-induced acute myocardial infarction to evaluate the lactate potential as an early diagnosis marker of cardiac ischemia. Materials and methods. Forty adult male rats were divided into 5 groups: sham (L1=11), control 0.9\% $\mathrm{NaCl}$ (L2=11), and with experimental myocardial infarction ( $\mathrm{L} 3=6, \mathrm{~L} 4=6$; $\mathrm{L} 5=6)$, induced by the subcutaneous injection of Isoproterenol Hydrochloride solution $100 \mathrm{mg} / \mathrm{kg}$, and sacrificed over 6 hours, 24 hours and 7 days post infarction. The results were presented by median and interquartile range. The groups were compared using Kruskal-Wallis and Mann-Whitney nonparametric tests, and the Spearman correlation coefficient was calculated (SPSS 23.0). A p $\leq 0.05$ was considered statistically significant.

\section{Résumé}

Lévaluation du lactate dans l'infarctus du myocarde expérimental aigu

Introduction. Le métabolisme est le facteur clé qui sous-tend la fonction cardio-myocytaire. La perfusion coronarienne inadéquate entraîne une acidose tissulaire due à une production élevée de lactate, qui est considérée comme un marqueur sensible de l'ischémie myocardique. L'isoprotérénol est une catécholamine synthétique qui produit une nécrose myocardique diffuse à fortes doses.

L'objectif de l'étude était d'évaluer les modifications de la teneur en lactate sérique et tissulaire dans l'infarctus du myocarde aigu induit par l'isoprotérénol afin d'évaluer le potentiel du lactate en tant que marqueur de diagnostic précoce de l'ischémie cardiaque.

Matériel et méthodes. Quarante rats mâles adultes ont été divisés en 5 groupes : sham ( $(\mathrm{L}=11)$, contrôle $0,9 \% \mathrm{NaCl}$ (L2=11), et avec un infarctus du myocarde expérimental (L3=6, L4=6; L5=6), induit par l'injection de solution de chlorhydrate d'isoprotérénol à 100 $\mathrm{mg} / \mathrm{kg}$, et sacrifiés pendant 6 heures, 24 heures et 7 jours après l'infarctus. Les résultats ont été présentés 
Results. Both glucose and lactate serum levels presented a slight decrease in L3, followed by a significant increase in L4, with a repeated fall in L5 group. In homogenate glucose content initially expressed an elevation in L3, with relevant decrease in L4, and inconsistent increase in $\mathrm{L} 5$, while lactate values significantly decreased in L3, returned to baseline levels in L4 and slightly declined in L5 compared to sham and control groups.

Conclusion. The collected data suggest the utility of lactate assessment in early diagnosis and risk stratification in acute myocardial infarction.

Keywords: isoproterenol, lactate, anaerobic metabolism, acidosis, acute myocardial infarction par la ligne médiane et interquartile. Les groupes ont été comparés à l'aide de tests non paramétriques de Kruskal-Wallis et de Mann-Whitney, et le coefficient de corrélation de Spearman a été calculé (SPSS 23.0). Une valeur $\leq 0,05$ a été considérée comme statistiquement significative.

Résultats Les taux sériques de glucose et de lactate présentaient une légère diminution dans le L3, suivie d'une augmentation significative dans le L4, avec une chute répétée dans le groupe L5. Dans l'homogénat, la teneur en glucose exprimait initialement une élévation dans L3, avec une diminution pertinente dans L4 et une augmentation incohérente dans L5, tandis que les valeurs de lactate diminuaient significativement dans L3, retournaient aux niveaux de base dans L4 et diminuaient légèrement dans L5 par rapport aux groupes sham et de contrôle.

Conclusions. Les données recueillies suggèrent l'utilité de l'évaluation du lactate dans le diagnostic précoce et la stratification du risque dans l'infarctus du myocarde aigu.

Mots-clés: isoprotérénol, lactate, métabolisme anaérobique, acidose, infarctus aigu du myocarde

conditions of increased lactate concentrations up to $60 \%$ of heart energy demands will be satisfied by lactate oxidation with direct ATP production via the mitochondrial shuttle ${ }^{7,8}$. The earliest alteration caused by inadequate coronary perfusion is the metabolic switch to anaerobic metabolism and myocardial tissue acidosis due to elevated lactate production?.

Lactate (2-hydroxypropanoate) is a hydroxycarboxylic acid formed in human cells mainly from glucose $(65 \%)$ and alanine (16-20\%) through their conversion into pyruvate, which is further reduced to lactate by a reversible oxidoreduction reaction catalysed by the cytosolic enzyme L-lactate dehydrogenase $(\mathrm{LDH})^{5,8,10,11}$. The thermodynamically favoured direction of the reaction is pyruvate reduction to produce L-lactate with simultaneous oxidation of reduced nicotinamide adenine dinucleotide (NADH) to nicotinamide adenine dinucleotide (NAD ${ }^{+}$. The opposite direction is oxidation of L-lactate to form pyruvate while $\mathrm{NAD}^{+}$is reduced to $\mathrm{NADH}^{10,12}$.

Lactate is removed through its conversion into pyruvate (via the system of intermembrane transporters) used for: 1) gluconeogenesis (Cori cycle) - the process exclusive to the liver and the kidney; 2) oxidation at rest state ${ }^{5,8,10}$.

A family of proton-linked monocarboxylate transporters (MCTs) facilitates lactate transportation through the cell membrane. There are fourteen MCTs described, but mainly MCT1 - MCT4 are 
involved in the lactate-pyruvate transport ${ }^{8,10}$. Based on transport kinetics, Gerlinger M. at el have proposed MCT4 as the main transporter responsible for the secretion of lactate out of human cells ${ }^{13}$. Experimental data confirm that an increase in $\mathrm{H}^{+}$concentration stimulates the transport of lactate, suggesting its role in mediating $\mathrm{H}+$ removal $^{8}$.

In the absence of ischemia, the cardiomyocytes simultaneously produce, release, uptake, and oxidize lactate ${ }^{3,8,10}$. The recent data suggest that lactate, a key metabolite in energy homeostasis, is crucial for intercellular cooperation, substrate distribution, and adaptation to injury ${ }^{8}$. The conversion of lactate to pyruvate by lactate dehydrogenase (LDH) and the accumulation of reduced nicotinamide adenine dinucleotide (NADH) activates specific NADH oxidase (NADox), ROS generation and modulates redox homeostasis in cardiac tissue $\mathrm{e}^{14}$. Hashimoto et al. have suggested that in myocytes, lactate may be involved in mitochondrial biogenesis through: *increased release of ROS; **the upregulation of genes encoding for MCT1 and COX; ${ }^{* * *}$ increased expression of the peroxisome proliferator activated-receptor $\gamma$ coactivator-1 $\alpha$ (PGC1 $\alpha$ ), and ${ }^{* * * *}$ DNA binding of the nuclear respiratory factor $2(\mathrm{NFR}-2)^{15}$.

Lactate homeostasis is linked to glucose metabolism ${ }^{10}$. Hypoperfusion and tissue hypoxia are promotors of anaerobic glucose metabolism ${ }^{5}$, while hyperglycaemia and inflammatory mediators are major determinants of increased lactate production ${ }^{8,16}$. Higher lactate levels indicate a stress response characterized by increased metabolic rate, sympathetic nervous system activation, accelerated glycolysis and a modified bioenergetic supply ${ }^{12,17}$. Acidaemia affects cell function by altering key enzymatic reactions, ATP generation mechanisms, fatty acid biosynthesis, myocardial contractile function, etc?

The accumulation of lactate has serious pathophysiological and clinical consequences such as altered acid-base balance and acidosis. According to pathogenic mechanisms, two types of lactic acidosis are described: *type A (fast) caused by oxygen deficits, and **type B (slow) due to compromised lactate metabolism without hypoxia (major metabolic dysregulation, certain drugs or toxins effects, congenital abnormalities in carbohydrate metabolism) ${ }^{11,18}$. The experimental studies have demonstrated that acidosis decreases the cardiac response to catecholamines and is a risk factor for arrhythmia development ${ }^{9,19}$.

Acute coronary syndrome, caused by impaired tissue oxygenation, stimulates anaerobic metabolism, increases production of lactic acid and delays its clearance, and leads to acidosis ${ }^{18}$. According to the published data, lactic acidosis is the most common cause of metabolic acidosis in hospitalized patients, being a predictor of decreased long-term survival ${ }^{20}$. Therefore, lactate can be considered a marker of tissue hypoperfusion and/or oxygen $\mathrm{debt}^{8}$, myocardial ischemia, and acidosis ${ }^{21}$.

Knowledge of the metabolic changes associated with acute myocardial ischaemia allows an early diagnosis to prevent the irreversible tissue damage.

Isoproterenol [1-(3,4-dihydroxyphenyl)-2isopropyl-aminoethanol hydrochloride (ISO)] is a synthetic catecholamine and powerful non-selective $\beta$-adrenergic agonist that at high doses (within 85-300 $\mathrm{mg} / \mathrm{kg}$ range) provokes severe stress, resulting in diffuse myocardial necrosis and fibrosis ${ }^{22}$. Isoproterenol induced myocardial injury is caused by generation through the autoxidation of highly cytotoxic free radicals and altered energy metabolism due to excessive oxidative stress, hyperglycaemia and acidosis ${ }^{22}$.

There is less data available in literature regarding the impact of isoproterenol on the lactate metabolism in vivo. Concomitantly there is a lack of conclusive evidence about the correlation between serum and tissue values of lactate in experimental cardiac ischemia.

The obJective OF THE STUDY was to assess serum and homogenate modifications of lactate in isoproterenol-induced acute myocardial infarction in rats, to evaluate the lactate potential as an early diagnosis marker of cardiac ischemia.

\section{Material AND MEthods}

The study was approved by the Research Ethics Committee of the "Nicolae Testemitanu" State University of Medicine and Pharmacy, Chisinau, Republic of Moldova (23.03.2015). Manipulations were carried out in the Laboratory of Biochemistry of the "Nicolae Testemitanu" State University of Medicine and Pharmacy in accordance with the institutional and national guide for the care and use of laboratory animals.

\section{Study design}

An experimental study was performed on 40 healthy white male rats (Ratta albicans) weighing 180-230 grams. The animals were kept at "Nicolae Testemitanu" State University of Medicine and Pharmacy, Chisinau, Republic of Moldova, in standard vivarium conditions: temperature $24 \pm 2^{\circ} \mathrm{C}$, 12-hours day/night cycle, free access to adequate food and water. The animals were fasted and received no water 12 hours prior to the sacrifice.

Myocardial infarction was induced by subcutaneous injection of a single dose of $100 \mathrm{mg} / \mathrm{kg}$ Isoproterenol Hydrochloride (Sigma Aldrich Chemie 
Table 1. Serum levels of glucose and lactate.

\begin{tabular}{|c|c|c|c|}
\hline \multicolumn{2}{|c|}{ Group } & $\begin{array}{l}\text { Glucose }(\mathrm{mM} / \mathrm{L}) \\
\mathrm{p}=0.0002^{* * *}\end{array}$ & $\begin{array}{c}\text { Lactate }(\mathrm{mM} / \mathrm{L}) \\
\mathrm{p}=0.169\end{array}$ \\
\hline L1 & Sham & 6.25 (IQR 0.45) & 4.91 (IQR 1.57) \\
\hline $\mathrm{L} 2$ & Control & 6.53 (IQR 0.94) & 4.69 (IQR 1.06) \\
\hline L3 & AMI.6h & 4.56 (IQR 0.55) & 4.09 (IQR 1.30) \\
\hline L4 & AMI.24h & 7.00 (IQR 1.56) & 5.85 (IQR 2.76) \\
\hline L5 & AMI.7d & 6.02 (IQR 0.75) & 4.48 (IQR 1.67) \\
\hline
\end{tabular}

Note: statistically significant difference in relation to the values of the sham group: ${ }^{*} \mathrm{p}<0.05 ;{ }^{* *} \mathrm{p}<0.01 ;{ }^{* * *} \mathrm{p}<0.001$

Table 2. Glucose and lactate values in cardiac homogenate.

\begin{tabular}{|c|c|c|c|}
\hline \multicolumn{2}{|c|}{ Group } & $\begin{array}{c}\text { Glucose }(\mathrm{mM} / \mathrm{g} / \mathrm{prot}) \\
\mathrm{p}=0.113\end{array}$ & $\begin{array}{l}\text { Lactate }(\mathrm{mM} / \mathrm{g} / \mathrm{prot}) \\
\qquad \mathrm{p}=0.007^{* *}\end{array}$ \\
\hline L1 & Sham & 4.94 (IQR 1.09) & 4.32 (IQR 0.41) \\
\hline L2 & Control & 4.43 (IQR 1.02) & 4.28 (IQR 0.64) \\
\hline L3 & AMI.6h & 4.97 (IQR 0.84) & $3.47^{*}$ (IQR 0.80) \\
\hline L4 & AMI.24h & 4.37 (IQR 0.56) & 4.33 (IQR 0.44) \\
\hline L5 & AMI.7d & 4.72 (IQR 0.35) & $3.91 * *(I Q R ~ 0.23)$ \\
\hline
\end{tabular}

Note: statistically significant difference in relation to the values of the sham group: ${ }^{*} p<0.05$; ${ }^{* *} p<0.01 ;{ }^{* *} p<0.001$

$\mathrm{GmbH}$ ) dissolved in $\mathrm{NaCl}$ 0.9\% solution. According to the study design, the animals were randomly divided into 5 groups: sham (L1=11) - no intervention; control (L2=11) - animals that were administered $\mathrm{NaCl}$ 0.9\% solution; experimental ( $\mathrm{L} 3=6 ; \mathrm{L} 4=6$; $\mathrm{L} 5=6$ ) - animals receiving $100 \mathrm{mg} / \mathrm{kg}$ isoproterenol hydrochloride subcutaneously. The rats were sacrificed under sterile conditions and sulphuric ether anaesthesia over 6 hours (L3 AMI6h), 24 hours (L4 AMI24h) and 7days (L5 AMI7days) post infarction.

\section{Sample collection}

Apical cardiac tissue $(300 \mathrm{mg})$ was homogenized in ice with $3 \mathrm{~mL}$ of $0.25 \mathrm{M}$ sucrose buffer $(\mathrm{pH}=7.4)$. The obtained homogenate was treated with $30 \mu \mathrm{L}$ of Triton X-100, placed in the refrigerator for 30 minutes, and centrifuged at $4^{\circ} \mathrm{C}$ at $3000 \mathrm{rpm}$ for 10 minutes. The supernatant was stored at $-40^{\circ} \mathrm{C}$ until analysis.

The collected blood samples were placed for 30 minutes into test-tubes allowing clotting, and then centrifuged for 10 minutes at $1500 \mathrm{rpm}$. Serum was collected in Eppendorf tubes and kept at $-40^{\circ} \mathrm{C}$ until analysis.

\section{Biochemical analysis}

Glucose and lactate levels were assessed in serum and tissue samples. Both glucose and lactate were measured using the ELITech assay kit (France) and manufacturer's instructions and the results were expressed in $\mathrm{mM} / \mathrm{L}$ (serum) and $\mathrm{mM} / \mathrm{g}^{*}$ protein (tissue). The markers were measured in five groups, including sham, control and experimental animals.

\section{Statistical analysis}

The obtained data were processed using SPSS 23.0 software. The descriptive statistics methods were used for median and interquartile range (IQR) calculation. Kolmogorov-Smirnov and Shapiro-Wilk normality tests were applied to analyse data distribution. The homogeneity of variance was evaluated by Levene's test. The groups were compared using Kruskal-Wallis and Mann-Whitney nonparametric tests. The correlation coefficient was calculated by the Spearman correlation test. The $\mathrm{p}<0.05$ value was considered statistically significant.

\section{Results}

The groups showed a statistically significant difference in serum glucose $\left(\mathrm{p}=0.0002^{* * *}\right)$ and statistically insignificant difference for serum levels of lactate $(\mathrm{p}=0.17)$. Both glucose and lactate serum levels presented a slight decrease in L3, followed by a significant increase in $\mathrm{L} 4$, with a repeated fall in L5 group (Table 1).

There were no differences in glucose $(\mathrm{p}=0.113)$ content in the homogenate, while tissue lactate values registered statistically significant variations $\left(p=0.007^{* *}\right)$. Glucose content initially expressed an 
elevation in L3, with relevant decrease in L4, and inconsistent increase in L5, while tissue lactate values significantly decrease in L3, return to baseline levels in L4 and slightly decline in L5 compared to sham and control groups (Table 2).

We identified the tendency of a strong negative correlation between lactate variables in serum and homogenate in L3 $(\rho=-0.714, p$ (one tailed $)=0.055)$. No correlations were found between serum glucose and lactate levels $(p=0.84)$, neither between glucose and lactate values in the homogenate $(\mathrm{p}=0.371)$.

\section{Discussion}

Lactate, a compound widely produced in tissues, is pivotal for energy homeostasis. Enhanced adrenergic stimulation results in increased production of lactate and stress hyperlactatemia ${ }^{7,17}$ that has a deleterious effect on the myocardium.

In 2018, Di Marino et al. noticed that prolonged myocardial ischaemia is biochemically well profiled by the release of cell injury markers, while early short periods of ischaemia are usually undiagnosed ${ }^{23}$. The previously published data suggested that the development of tissue acidosis and lactate production can be considered sensitive markers of the onset of myocardial ischemia, due to inadequate oxygenation of myocardium ${ }^{24}$.

Jovanovic et al. suggested that low tissue oxygenation and anaerobic glucose metabolism lead to amplified lactate production in acute myocardial infarction ${ }^{18}$. Wang et al reported that under conditions of ischemia, lactate values reliably reflect the metabolic modifications caused by tissue hypoxia, oxidative stress, and cardiac injury ${ }^{21}$. Therefore, myocardial production of lactate is considered a marker of anaerobic metabolism that correlates to the degree of ischemia ${ }^{25}$, while myocardial extraction of lactate is an accepted standard for the quantification of myocardial ischaemia ${ }^{23}$.

Our study identified a decrease in serum lactate level by 20\% AMI.6h group, then an increase in lactate concentration by $36 \%$ in AMI24h group, and the repeated decrease by $28 \%$ in AMI.7d group. Tissue values of lactate showed the same tendency to change, but at a lower level in the state of infarction, they have initially decreased by $20 \%$ in AMI6h group compared to sham animals, then dynamically returned to the baseline in AMI24h group, and inconclusively declined by $10 \%$ in AMI7d group.

Our results coincide with those reported by Di Marino et al. (2018), who have observed that in balloon-induced ischemia systemic arterial lactate concentration decreased constantly, being after 10 minutes by $30 \%$ lower than the initial leve ${ }^{23}$.
The prognostic role of lactatemia in patients with acute coronary syndromes is still controversial $^{18}$. Khuri et al. have reported a direct correlation between the severity of acidosis during myocardial ischemia, and the patients' outcome $\mathrm{e}^{20}$. Jovanovic et al. established that lactate levels indicate increased risk for poor outcome in diabetic patients with acute myocardial infarction ${ }^{18}$. Onorati et al. have shown that higher lactate levels during reperfusion correlated with severe hemodynamic complications ${ }^{24}$.

The research performed by Rao et al. established that during reperfusion the continuous release of lactate is suggestive for delayed return to normal (aerobic) myocardial metabolism and postoperative low output syndrome ${ }^{26}$. According to results published in 2012 by Attana, the dynamic changes in serum lactate (absolute values) reflect the haemodynamic status, allow an early risk stratification, as well as the monitoring and evaluation of the therapeutic strategy ${ }^{17}$.

The available data indicate that serum lactate concentration influences on prognosis of cardiovascular diseases 5 . Multiple studies showed off the utility of serum levels of lactate as independent predictors, which reflects the severity of complications and the outcomes. Lazzeri et al. (2012) and Hayiroglu et al. (2017) demonstrated the relationship between blood lactate and in hospital short-term mortality in STEMI patients ${ }^{16,27}$. Attana et al. established that serum lactate levels, assessed on arrival in emergency department, are predictive for future severe complications (congestive heart failure, arrhythmias, cardiogenic shock, etc.), and poor short-term outcome after AMI ${ }^{17}$. Kawase et al. (2015) have reported the relation between elevated blood lactate at presentation and increased mortality in acute decompensated heart failure ${ }^{28}$. Frydland et al. identified an independent association of admission lactate concentration with 30-day mortality and development of late cardiogenic shock ${ }^{29}$.

The study conducted in 2018 by Gjesdal et al. noticed that, in patients with acute coronary syndrome and signs of heart failure, lactate analysed as a continuous variable significantly correlated to shortand long-term mortality ${ }^{30}$. According to the published data, the serial lactate measurements are more reliable and advisable for risk stratification in acute cardiac patients ${ }^{7}$, as well as for prognosis assessment ${ }^{8}$.

The recently published data suggest the use of lactate as a cost-effective diagnostic tool to evaluate the risk of serious complications ${ }^{7}$, and as prognostic marker in patients with acute coronary syndrome and cardiogenic shock ${ }^{16,17,31}$.

Both the lack of correlation between glucose and lactate levels in serum and homogenate, and the tendency of a strong negative correlation between lactate variables in above-mentioned samples suggest the 
need for a careful interpretation of lactate levels in blood considering the clinical context.

The dynamic changes of lactate in ISO-induced cardiac ischemia reflects the anaerobic glucose metabolism due to perturbation of tissue oxygenation that leads to the oxidative stress ${ }^{18}$. Multiple clinical trials have shown that elevated lactate values are associated with severe complications ${ }^{17}$, increased mortality ${ }^{7,27-29}$, being used as markers of acute ischemic heart lesions, and/or as prognostic factors. It is incontestable that the regularly found metabolic changes facilitates the identification of acute cardiac ischemia and can be used as reliable predictors of disease prognosis.

\section{Conclusions}

The study findings confirm the changes in serum and tissue values of lactate in experimental myocardial infarction induced by isoproterenol and highlights biochemical mechanisms underlying its detrimental effects. The accumulation of lactate reflects the degree of tissue hypoxia and oxidative stress, predicting the severity of myocardial lesions and the risk for developing major complications. The assessment of serum and tissue levels of lactate is useful for the diagnosis and risk stratification in acute myocardial infarction.

\section{Author Contributions:}

Conceptualization, V.T. and T.T.; methodology, T.T.; software, V.T; validation, V.T. and T.T.; formal analysis, V.T.; investigation, V.T. and T.T; data curation, V.T. and T.T.; writing-original draft preparation, V.T.; writing-review and editing, T.T.; supervision, T.T. All the authors have read and agreed with the final version of the article.

\section{Compliance with Ethics Requirements:}

"The authors declare no conflict of interest regarding this article"

"The authors declare that all the procedures and experiments of this study respect the institutional and national guide for the care and use of laboratory animals, as well as the national law."

"No funding for this study"

\section{Acknowledgements:}

None

\section{REFERENCES}

1. European Cardiovascular Disease Statistics 2017. European Heart Network. Available from: www.ehnheart.org/cvdstatistics.html.
2. Gibb AA, Hill BG. Metabolic coordination of physiological and pathological cardiac remodeling. Circulation Research 2018;123:107-128.

3. Bergman BC, Tsvetkova T, Lowes B, Wolfel EE. Myocardial glucose and lactate metabolism during rest and atrial pacing in humans. The Journal of Physiology 2009;587(9):2087-2099.

4. Khabbaz KR, Zankoul F, Warner KG. Intraoperative metabolic monitoring of the heart: online measurement of myocardial tissue $\mathrm{pH}$. The Annals of Thoracic Surgery 2001;72(6):2227-34.

5. Kubiak GM, Tomasik AR, Bartus K, Olszanecki R, Ceraniwicz P. Lactate in cardiogenic shock - current understanding and clinical implications. Journal of Physiology and Pharmacology 2018;69(1):15-21.

6. Beadle RM, Frenneaux M. Modification of myocardial substrate utilisation: a new therapeutic paradigm in cardiovascular disease. Heart 2010;96(11):824-830.

7. Lazzeri C, Valente S, Chiostri M, Gensini GF. Clinical significance of lactate in acute cardiac patients. World Journal of Cardiology 2015;7(8):483-489.

8. Gómez H, Mizock BA. Hyperlactatemia and lactic acidosis. Critical Care Nephrology 2019;394-404.e3.

9. Raicea V, Kovacs J, Moraru L, Suciu H. Coronary sinus lactate as marker of myocardial ischemia in cardiac surgery: correlation with morbidity and mortality after cardiac surgery. Revista Romana de Medicina de Laborator 2015;23(2):189-197.

10. Adeva-Andany M, López-Ojén M, Funcasta-Calderón R, et al. Comprehensive review on lactate metabolism in human health. Mitochondrion 2014;17:76-100.

11. Luft FC. Lactic acidosis update for critical care clinicians. Journal of the American Society of Nephrology 2001;12(17):S15-9.

12. Le A, Cooper CR, Gouw AM, et al. Inhibition of lactate dehydrogenase $A$ induces oxidative stress and inhibits tumour progression. Proceedings of the National Academy of Sciences of the United States of America 2010;107(5):2037-2042.

13. Gerlinger M, Santos CR, Spencer-Dene B, et al. Genome-wide RNA interference analysis of renal carcinoma survival regulators identifies MCT4 as a Warburg effect metabolic target. The Journal of Pathology 2012;227(2):146-156.

14. Gabriel-Costa D, Cunha TF, Paixão NA, et al. Lactate-upregulation of lactate oxidation complex-related genes is blunted in left ventricle of myocardial infarcted rats. Brazilian Journal of Medical and Biological Research 2018;51(11):e7660.

15. Hashimoto T, Hussien R, Oommen S, Gohil K, Brooks GA. Lactate sensitive transcription factor network in L6 cells: activation of MCT1 and mitochondrial biogenesis. The FASEB Journal 2007;21(10):2602-2612.

16. Lazzeri C, Valente S, Chiostri M, Picariello C, Gensini GF. Lactate in acute phase of ST-elevation myocardial infarction treated with mechanical revascularization: a single-center experience. American Journal of Emergency Medicine 2012;30(1):92-96.

17. Attanà $\mathrm{P}$, Lazzeri $\mathrm{C}$, Picariello $\mathrm{C}$, Dini CS, Gensini, GF, Valente S. Lactate and lactate clearance in acute cardiac care patients. European Heart Journal: Acute Cardiovascular Care 2012;1(2):115-121.

18. Jovanovic A, Peric V, Markovic-Jovanovic S, Stolic R, Mitic J, Smilic T. Hyperlactatemia and the outcome of type 2 diabetic patients suffering acute myocardial infarction. Journal of Diabetes Research, 2016. Article ID 6901345, 7 pages.

19. Schotola H, Toischer K, Popov AF, et al. Mild metabolic acidosis impairs the $\beta$-adrenergic response in isolated human failing myocardium. Critical Care 2012;16(4):R153. 
20. Khuri SF, Healey NA, Hossain M, et al. Intraoperative regional myocardial acidosis and reduction in long-term survival after cardiac surgery. The Journal of Thoracic and Cardiovascular Surgery 2005;129:372-381.

21. Wang X, Wang D, Wu J, et al. Metabolic characterization of myocardial infarction using GC-MS-based tissue metabolomics. International Heart Journal 2017;58(3):441-446.

22. Mahammad Rahmathulla SB, Lakshmi Devi K. Origination and development of isoproterenol-induced myocardial infarction in male Wistar rats. International Research Journal of Pharmacy 2013;4(5):26-35.

23. Di Marino S, Viceconte N, Lembo A, et al. Early metabolic response to acute myocardial ischaemia in patients undergoing elective coronary angioplasty. Open Heart 2018;5(1):e000709.

24. Onorati F, Cristodoro L, Caroleo S, et al. Troponin I and Lactate from coronary sinus predict cardiac complications after myocardial revascularization. The Annals of Thoracic Surgery 2007;83(3):1016-1023.

25. Kapoor PM, Mandal B, Chowdhury UK, Singh SP, Kiran U. Changes in myocardial lactate, pyruvate and lactate-pyruvate ratio during cardiopulmonary bypass for elective adult cardiac surgery: early indicator of morbidity. Journal of Anaesthesiology Clinical Pharmacology, 2011;27(2):225-232.
26. Rao V, Ivanov J, Weisel RD, Cohen G, Borger MA, Mickle DA. Lactate release during reperfusion predicts low cardiac output syndrome after coronary bypass surgery. The Annals of Thoracic Surgery 2001;71(6):1925-1930.

27. Hayiroglu MI, Keskin M, Uzun AO, et al. Predictors of in-hospital mortality in patients with ST-segment elevation myocardial infarction complicated with cardiogenic shock. Heart, Lung $\mathcal{E}$ Circulation 2019;28(2):237-244.

28. Kawase T, Toyofuku M, Higashihara T, et al. Validation of lactate level as a predictor of early mortality in acute decompensated heart failure patients who entered intensive care unit. Journal of Cardiology 2015;65(2):164-170.

29. Frydland M, Møller JE, Wiberg S, et al. Lactate is a prognostic factor in patients admitted with suspected ST-elevation myocardial infarction. SHOCK 2019;51(3):321-327.

30. Gjesdal G, Braun OÖ, Smith JG, Scherstén F, Tydén P. Blood lactate is a predictor of short-term mortality in patients with myocardial infarction complicated by heart failure but without cardiogenic shock. BMC Cardiovascular Disorders 2018;18(1):8.

31. Moisi MI, Bungau SG, Vesa CM, et al. Framing cause-effect relationship of acute coronary syndrome in patients with chronic kidney disease. Diagnostics 2021;11(8):1518. 